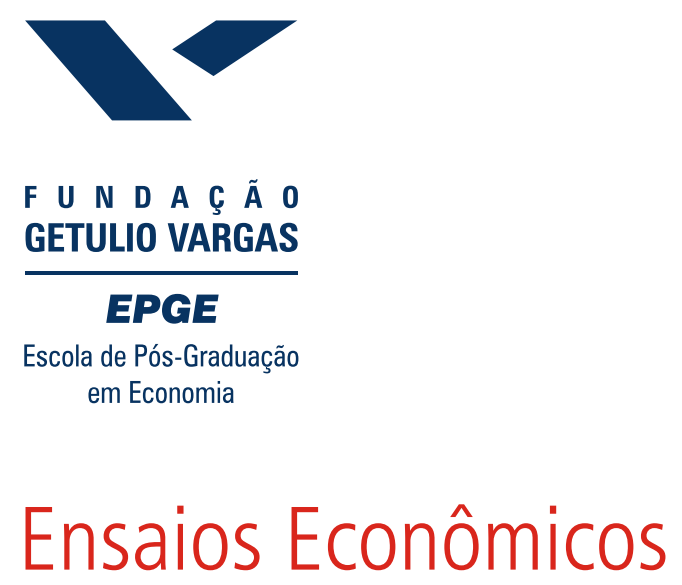

$$
\begin{aligned}
& \text { Escola de } \\
& \text { Pós Graduação } \\
& \text { em Economia } \\
& \text { da Fundação } \\
& \text { Getulio Vargas }
\end{aligned}
$$

$\mathbf{N}^{\circ} 669$

ISSN 0104-8910

Brazil: Steps Toward Investment Grade

Rubens Penha Cysne, Paulo Gustavo Grahl

Janeiro de 2008 
Os artigos publicados são de inteira responsabilidade de seus autores. As opiniões neles emitidas não exprimem, necessariamente, o ponto de vista da Fundação Getulio Vargas. 


\title{
Brazil: Steps Toward Investment Grade $^{1}$
}

\author{
Rubens Penha Cysne ${ }^{2}$ \\ Paulo Gustavo Grahl ${ }^{3}$
}

\footnotetext{
${ }^{1}$ This work derives from the book "Brasil: Uma Análise das Contas Externas", by the same authors. The present text has been last revised on December 2006 and is based on data available at that date. A further classification of Brazil's sovereign debt one step below investment grade (by Fitch and Standard \& Poor's, as $\mathrm{BB}+$ ) has occurred in 2007, but is not taken into consideration in the present analysis (at the time the text was written the classification was $\mathrm{BB}$ positive/perspective towards $\mathrm{BB}+$, a fact posteriorly confirmed). The authors have not revised the translation to English. Guilherme Babo Torres and Felipe Balassiano, from the Getulio Vargas Foundation, provided able research assistance.

${ }^{2}$ Getulio Vargas Foundation.

${ }^{3}$ Getulio Vargas Foundation.
} 


\section{Brazil's Current Position}

Brazil's sovereign risk classification, as evaluated by the main risk classification agencies ${ }^{4}$, has improved over the last several years. On November 22, 2006, it reached its highest sovereign risk classification (BB/positive perspective, according to S\&P.) However, this improvement has been quite gradual if compared, for example, with the evolution of risk classification for some countries normally evaluated by international investors in conjunction with Brazil. This is made clear by Illustration 1 below:

Illustration 1: Evolution of Sovereign Risk: Selected countries

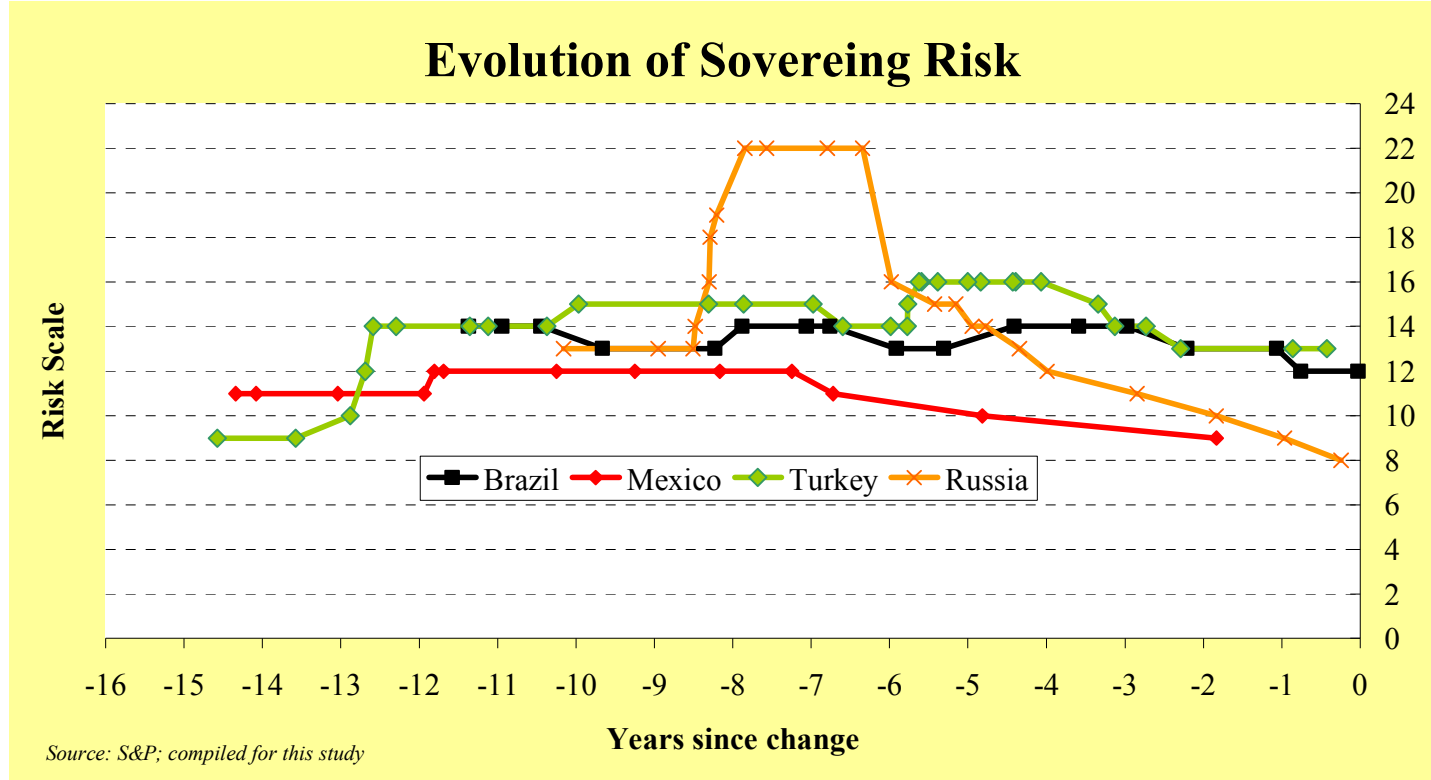

Illustration 1 shows the historical evolution of sovereign risk for Brazil, Mexico, Turkey and Russia. The scale of the graph represents the different classifications of risk defined by $\mathrm{S} \& \mathrm{P}$, where 1 represents the highest classification (AAA) and 22 represents a default (D) situation. The classifications defined by the agency are: D, C, CC, CCC-, CCC, $\mathrm{CCC}+, \mathrm{B}-, \mathrm{B}, \mathrm{B}+, \mathrm{BB}-, \mathrm{BB}, \mathrm{BB}+, \mathrm{BBB}-, \mathrm{BBB}, \mathrm{BBB}+, \mathrm{A}-, \mathrm{A}, \mathrm{A}+, \mathrm{AA}-, \mathrm{AA}, \mathrm{AA}+$, $\mathrm{AAA}$. Thus, on the graph, the degree of investment (investment grade, or any classification better than BBB-) is represented by the part of the graph whose numeric is less than or equal to 10 .

The graph highlights, for example, that about 11 years ago (in 1995) the sovereign risk classifications of Brazil and Turkey were the same $(\mathrm{B}+)$, while currently (November, 2006) Brazil is classified as BB/positive perspective and Turkey as BB-/stable perspective. However, we can also see that for the last 4 years Russia has shown an improvement of 4 levels in risk classification, Turkey of 3 levels and Brazil of just 2 levels 5 . In comparing Brazil with the 113 countries analyzed by S\&P, we can observe that $62 \%$ have a sovereign risk inferior to that of Brazil (at its best position), 31\% have

\footnotetext{
${ }^{4}$ Standard and Poor's, Fitch, and Moody's

${ }^{5}$ Note that this is a partial analysis, for illustrative purposes, and only considers the sovereign risk classification given by S\&P.
} 
a greater risk, and 7\% have the same risk classification (Columbia, Costa Rica, Guatemala, Jordan, Montenegro, Panama, and Vietnam). Illustration 2 depicts this situation:

\section{IIlustration 2: Sovereign risk: Selected countries}

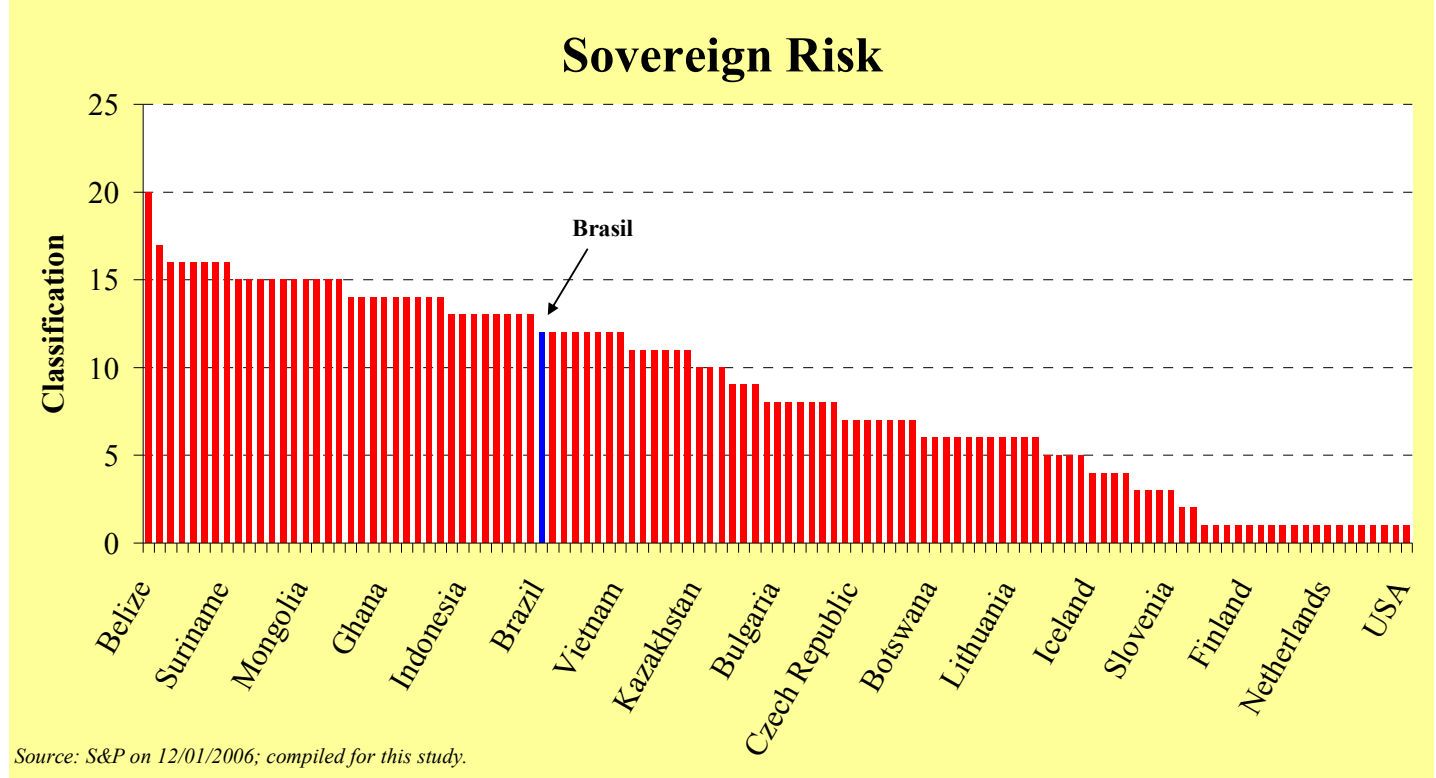

On November 22, 2006, the risk classification agency S\&P changed its perspective on Brazil's sovereign risk classification for long-term debt in foreign currency from $\mathrm{BB} /$ stable to $\mathrm{BB} /$ positive. In principal, this suggests that within a year there could be an improvement in Brazil's risk classification to $\mathrm{BB}+$. If confirmed ${ }^{6}$ as $\mathrm{BB}+$, one more advance will lead to investment grade ${ }^{7}$. By the BB positive perspective classification, S\&P pointed primarily to the continuing reduction in external and fiscal vulnerabilities, and the expectation that, during the current administration's second mandate, the focus would be on a progressive reduction of fiscal rigidity. In particular, the agency highlighted two main points to be solved: the elevated levels and low quality of both government spending and taxation, arguing that the finding of a solution to these two problems would improve not only the fiscal situation but also that of investment and growth.

In general, to better understand the steps that are necessary for Brazil to continue to improve its sovereign risk as evaluated by risk classification agencies, one must understand what elements are analyzed by these agencies when they determine a country's credit risk, and this is described in the next section ${ }^{8}$.

\footnotetext{
${ }^{6}$ As it actually came to happen in 2007.

${ }^{7}$ The investment grade is particularly important because, among other things, some foreign investment funds (for example, pension funds in the USA) are limited by their by-laws to investing only in assets that have a risk classification greater than or equal to investment grade (assets whose classification are below investment grade are considered speculative.)

${ }^{8}$ The methodologies used by risk classification agencies are not exactly the same; this section is based upon the methodology used by S\&P.
} 


\section{Sovereign Credit Risk}

Sovereign credit risk evaluations attempt to summarize the ability and commitment of an economy to honor its liabilities as compared to other countries with a single indicator. These indicators include obligations in national and foreign currency, and both long and short-term liabilities, although the most widely observed indicator is the classification of the sovereign credit risk for long-term debt in foreign currency ${ }^{9}$. The importance to a country of obtaining a good risk classification can be summarized by illustration 3:

IIlustration 3: Sovereign Risk vs. Interest Rates ${ }^{10}$

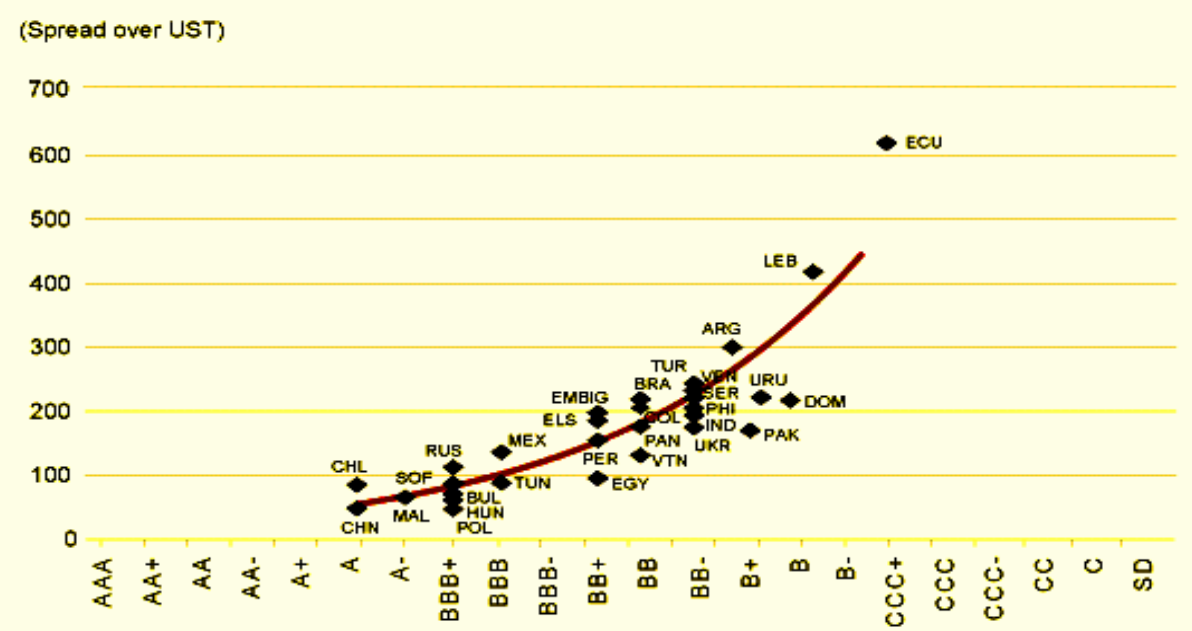

Source: S\&P (11/30/2006)

In general, we discover that countries with a risk classification considered to be investment grade $\left(\mathrm{BBB}^{11}\right)$ had, at the end of November 2006, a cost for raising capital of between 40 and 100 base points ${ }^{12}$, while the countries with the same risk classification as Brazil (BB) had a cost of raising capital of about 120 to 210 base points.

In addition to the direct impact on the cost of raising external resources for the government, we can also point to the indirect impact of country risk on the costs of

\footnotetext{
${ }^{9}$ On Dec/1/2006 Brazil was classified as a BB risk in foreign currency / long-term, B risk in foreign currency / short-term, BB+ risk in national currency / long-term, and B risk in national currency / short-term.

${ }^{10}$ Measured by the EMBI index (Emerging Markets Bond Index) calculated by JPMorgan Bank, this represents the difference between a country's cost of raising capital in comparison the cost of raising capital for the US Treasury.

${ }^{11}$ Investment Grade.

${ }^{12}$ For example, 50bp (base points) means that, roughly speaking, a country pays interest rates on its foreign securities equal to the rate of US treasury bonds (about $4.5 \%$ per annum on a tenyear bond) plus $0.5 \%$ per annum.
} 
raising capital for the private sector ${ }^{13}$, and the impact on the availability of external resources for the country, since many investment funds have restrictions on investing in countries whose classification is less than investment grade $(B B B)$.

A country's risk classification is an estimate in regard to the probability of sovereign default (credit risk), and not a measure of others risks in regard to the country, such as, for example, exchange-rate risk, regulatory risk, etc ${ }^{14}$. The table below shows an ex-post comparison between the rate of default for countries and corporations, for horizons of 1 to 5 years, per category of risk. Observe that the default rate is generally less for countries than for corporations:

Table 1 Comparsion between Coutries and Corporations

\begin{tabular}{|l|c|c|c|c|c|c|}
\hline \multicolumn{6}{|c|}{ Comparsion between Coutries and Corporations } \\
\hline & \multicolumn{2}{|c|}{ 1 year } & \multicolumn{2}{c|}{3 years } & \multicolumn{2}{c|}{5 years } \\
\hline (\%) & Country & Corporation & Country & Corporation & Country & Corporation \\
\hline AAA & 0 & 0 & 0 & 0 & 0 & 0.1 \\
\hline AA & 0 & 0 & 0 & 0.1 & 0 & 0.3 \\
\hline A & 0 & 0 & 0 & 0.2 & 0 & 0.6 \\
\hline BBB & 0 & 0.3 & 2.1 & 1.3 & 5.6 & 2.8 \\
\hline BB & 1.1 & 1.1 & 5.6 & 6.0 & 8.8 & 10.7 \\
\hline B & 3.0 & 5.4 & 8.8 & 17.1 & 17.6 & 24.2 \\
\hline CCC/CC & 40.0 & 27.0 & 58.9 & 40.9 & 58.9 & 47.6 \\
\hline
\end{tabular}

Source: Standard and Poor's

These ex-post frequency measurements are occasionally presented as an indicator of the quality of their services.

Among the main topics / categories analyzed by risk classification agencies in order to determine credit risk are:

- Political risk;

- Economic and income structure;

- Economic growth;

- Fiscal policy;

- Public debt;

- Monetary policy;

- External liquidity;

- External debt;

Within these categories, items such as geopolitical risk, stability of institutions, efficiency of the public sector, competitiveness of the private sector, savings and investments, government spending, composition and term of public debt, independence

${ }^{13}$ Except for some important exceptions (Petrobras, Vale do Rio Doce, etc.), the majority of Brazilian corporations have their minimum credit risk classification limited to the sovereign credit risk.

${ }^{14}$ Although they may be related. 
of Central Bank, composition of capital flow, external debt, service of external debt, etc., are analyzed qualitatively and quantitatively and a hierarchy among countries is made as a basis for defining the risk classification of an individual country.

Table 2 below contains some indicators commonly used by S\&P, classified according to the scale of risk, as well as Brazil's position on this scale. The data are estimates for 2006.

Table 2: Categories of Sovereign Risk

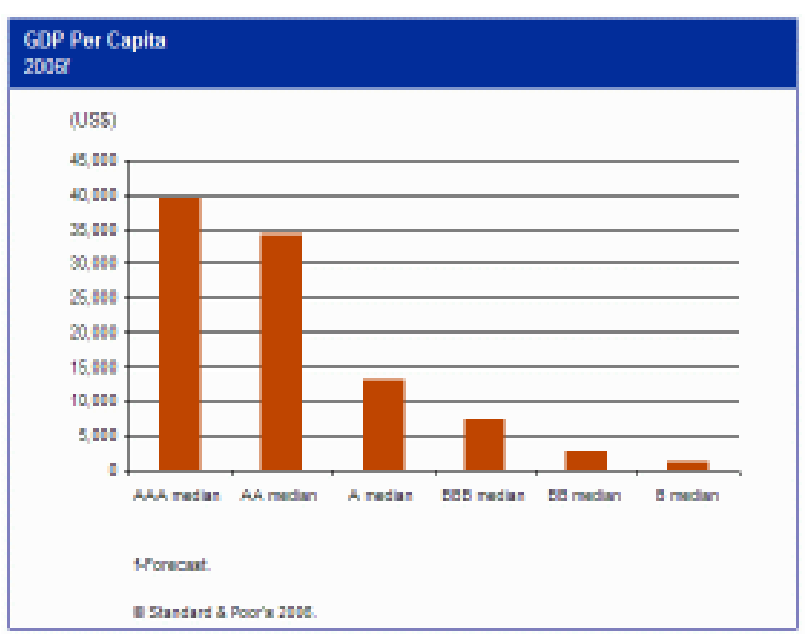

\section{${ }^{15}$ Income and Economic Structure:}

In general, market economies with well established property rights tend to be less subject to economic policy errors and pay more respect to the interests of creditors than economies dominated by the public sector. The economies of Western Europe and the US have higher classifications for this item. Reduction of fiscal imbalance, flexibility of the labor market, strengthening of the financial sector, and trade openness are the primary items observed in this category. According to S\&P, ranking in this category is strongly correlated with per capita income.

Brazil, with a per capita income of about $1 / 10$ the per capita income of the United States (when no correction is made for parity in purchasing power), obviously does not benefit from this analysis in the way that developed countries do.

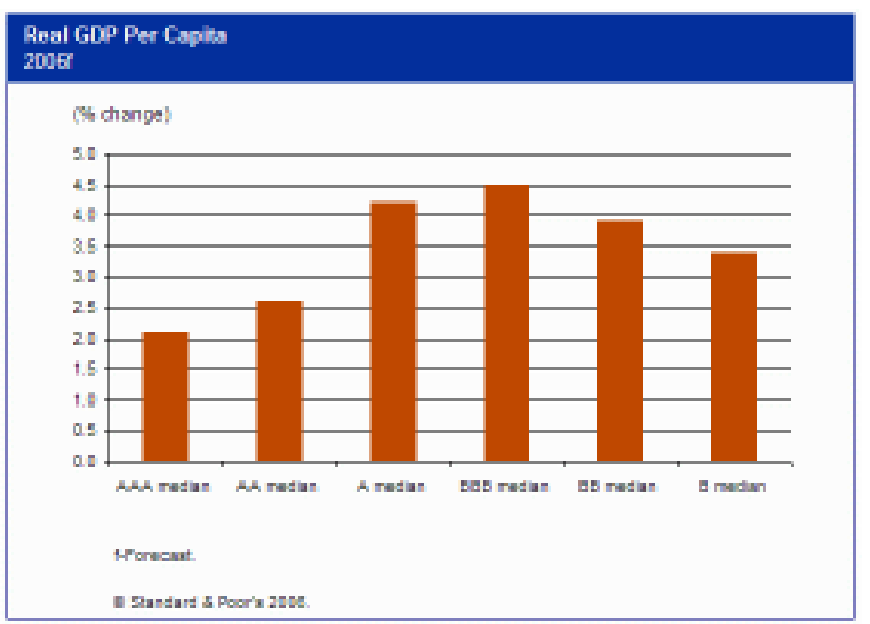

Economic Growth: in principal, a country that is growing consistently, increasing its standard of living and improving its distribution of income would have a greater probability of honoring its public debt when faced with economic and political shocks than a country with a stagnant economy.

Brazil appears in a negative light in this category, particularly when compared to other countries in the category of emerging economies.

\footnotetext{
${ }^{15}$ The estimates for Brazil in 2006 were collected from reports by the Central Bank of Brazil and private banks.
} 


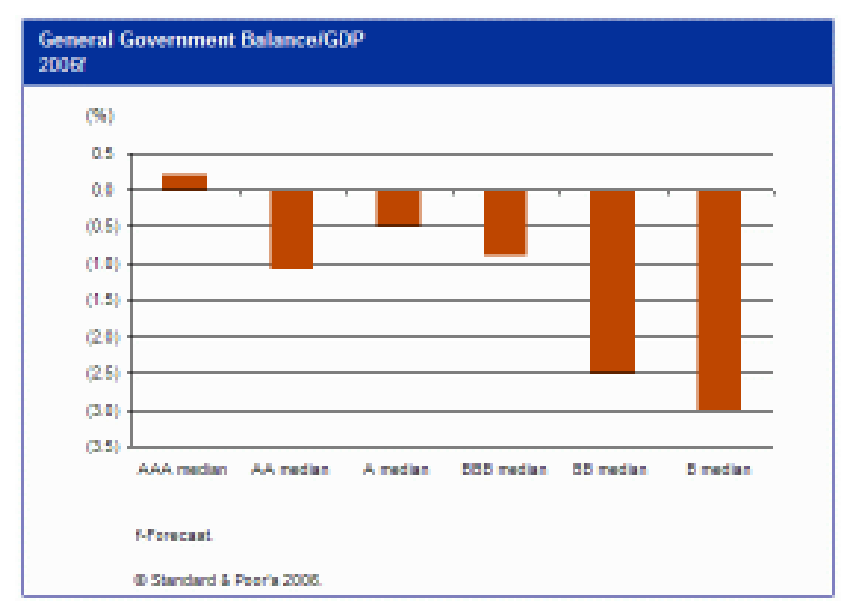

Fiscal Policy: receipts, expenditures and fiscal balance in the public sector are analyzed in this category. Fiscal tendencies, as well as the type of financing used for the public debt are important indicators of the quality of sovereign credit. Not only is the size of the government's surplus / deficit analyzed, but also the flexibility of its receipts and expenses and the efficiencies of public spending (including social security.)

An analysis of the tax system is also important, in regard to the distortions generated by taxes. Countries with a poor classification in this category are those in which government spending and tax distortions are excessively high relative to the benefits provided for the population.

Brazil, a country with public spending in the neighborhood of 40 of GDP, and in which the return on this spending is generally regarded as poor, doesn't usually fare well in this category. In addition, the tax system is widely evaluated as being greatly in need of improvement and a generator of strong distortions in the economy (in particular, for savings and investment.) 


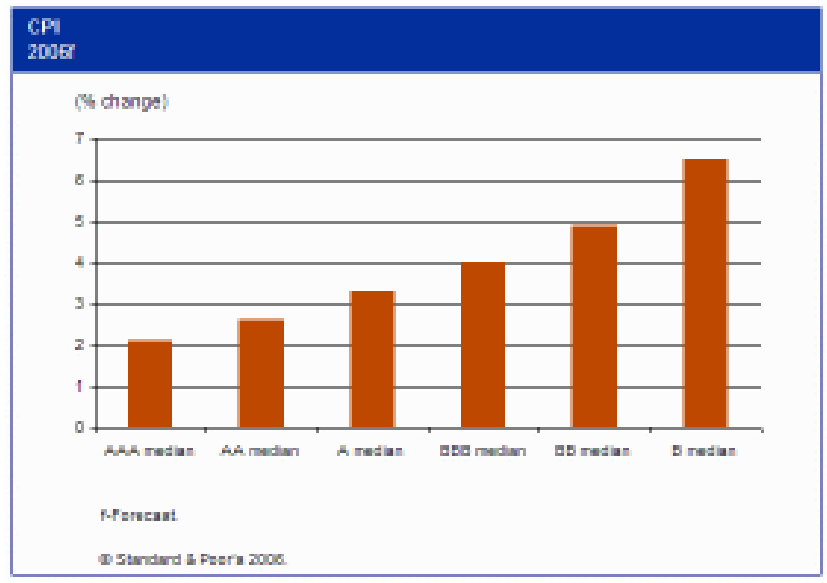

Monetary Policy: monetary flexibility is considered an important forward indicator for tendencies in sovereign credit risk. Generally speaking, productivity growth, global competition, greater independence of central banks, and wiser monetary policies have reduced the levels of inflation across the globe, although risks of a return of inflation are still present in the global scenario.

In this category, Brazil has appeared positively, with inflation forecast at less than $4.5 \%$ for 2006. As a result of a fiscal policy that has been characterized by continually rising spending, however, this policy has also brought negative side effects in regard to the formation of capital.

The high real interest rate (resulting from a budget with elevated public spending), associated with a floating exchange rate, has a negative influence on the composition of aggregate demand. The demand that usually generates productivity gains (trade and service balances, as well as private investment) is redirected in benefit of demand that doesn't generate capitalization for the future: private consumption and government consumption. 

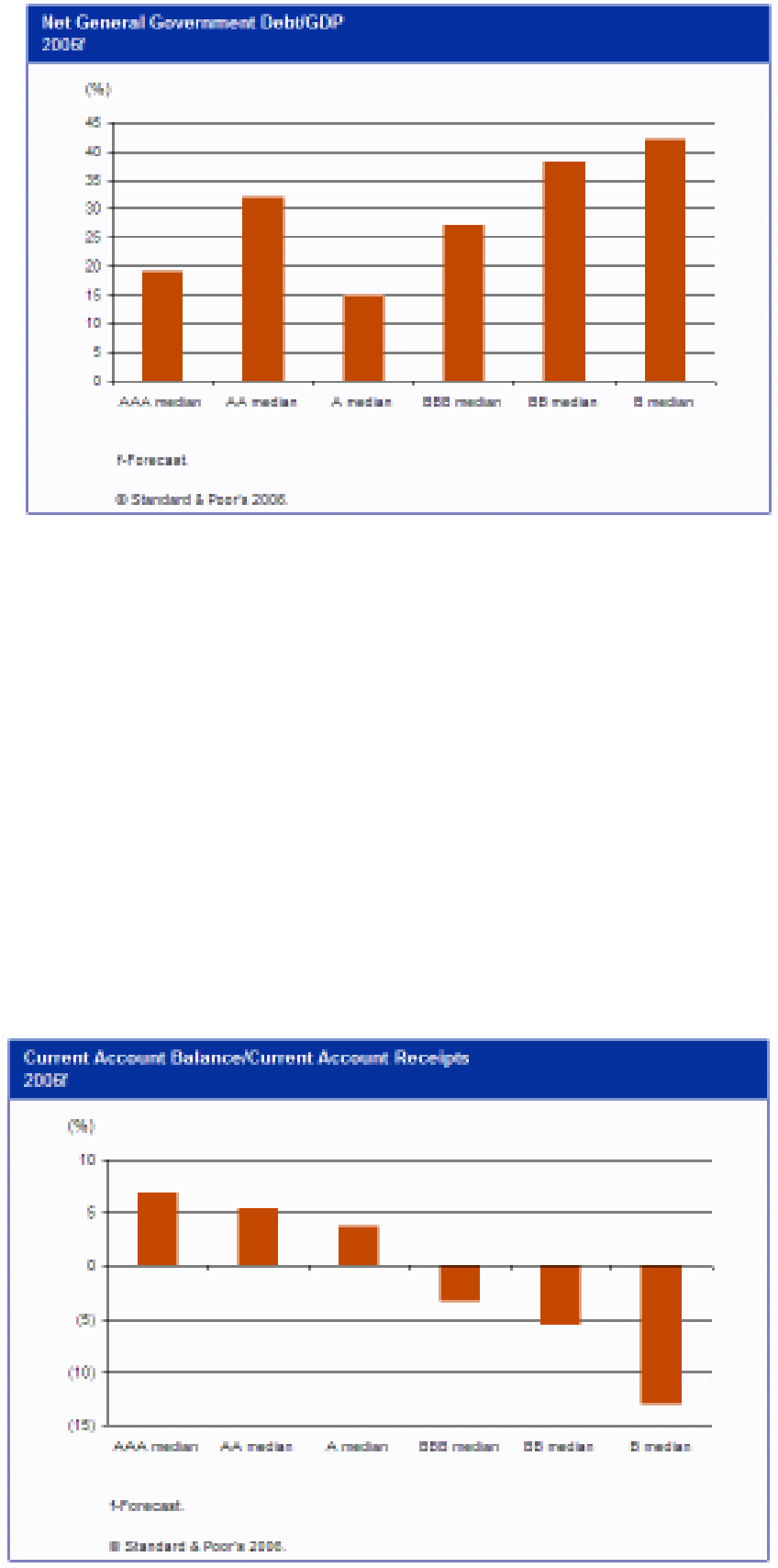

Net Debt in Public Sector: In general, the credit risk classification of a country is not as strongly related to public debt as it is to other indicators. A country with a history of honoring its commitments and whose financing of the public debt is done in a sophisticated market at low costs may have a better classification in this category than a country with a lower debt/GDP ratio but with a higher cost with debt service.

Brazil, despite having maintained a practically stable debt/GDP ratio in 2006 (estimated at $50 \%$ vs. $51.6 \%$ in 2005 ), showed substantial improvement in terms of its composition of debt, virtually eliminating the portion indexed to the exchange rate and reducing the indexation to short-term interest rates (which prevents the wealth effect on consumption and makes control of demand difficult by elevating interest rates.) However, as we observe in the graph, the Median for countries with investment grade is less than $30 \%$. Brazil still has a relatively low average term for public debt, which is a negative point.

External Liquidity: one of the more important indicators in this category is external financing needs (current account balance as a percentage of revenue from current accounts). According to S\&P, this indicator has a high correlation with risk classification, principally at intermediate risk levels. Factors that can attenuate risks with external financing need are direct investment $\left(\mathrm{DFI}_{1}{ }^{16}\right)$, and strong growth in exports.

Brazil, with a forecast for a current account surplus of $1.4 \%$ of GDP in 2006, about US\$16 billion in DFI, and US\$ 85 billion in international reserves, showed a substantial improvement in external solvency indicators over the last two years - although the degree of openness of markets and the relationship of net external debt / exports are still at lower levels than other countries with similar credit risk.

\footnotetext{
${ }^{16}$ Direct foreign investment.
} 


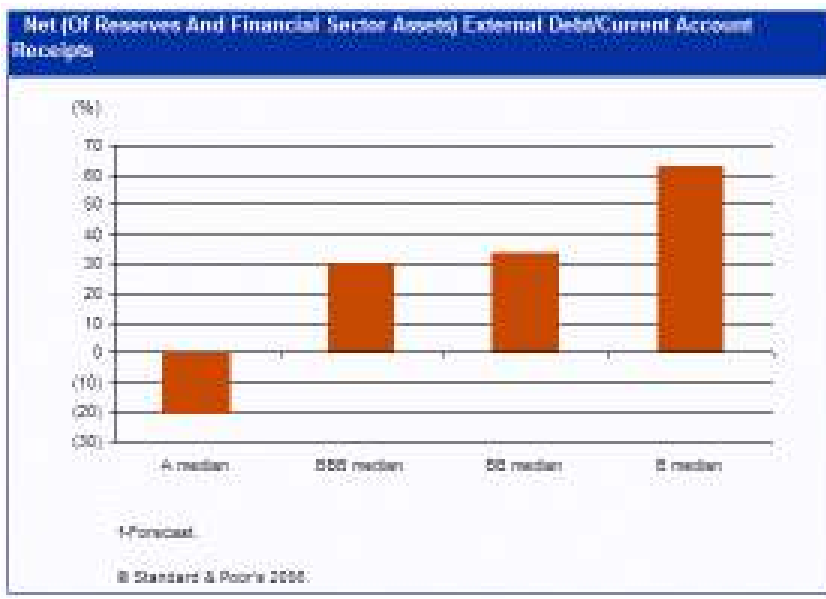

\section{Determinants of Sovereign Risk}

Based on section 2, we select some variables as a proxy for the categories of sovereign credit risk (see table 1) and evaluate the strength of these variables for explaining the risk classification of 68 countries. The variables used, each at a time, for illustrative purposes only, were: per capita GDP, GDP growth rate, inflation, nominal result of the government ( $\%$ of GDP), government debt ( $\%$ of receipts), current account results ( $\%$ of GDP), degree of openness, net external debt ( $\%$ of receipts in current account), a variable that is indicative of the occurrence or not of a moratorium in the past history of a certain country, and a variable that is an indicator that determines if a country is an industrialized economy or not.

The illustrations below 4 to 12 emphasize the comparison between country risk classification and the values obtained for the variables mentioned above. The reader should observe that they present only total correlations, not partial, and shouldn't be surprised if some correlations appear to be contrary to intuitive expectations. The usual multivariate analysis conveying the partial correlations is presented in the appendix to this work.
External Debt: a detailed analysis of classification relative to other are normalized by current account with regard to maturity dates, composition, sensibility to interest rates, etc.

Arazil had a Net External Debt / ratio of $58 \%$ for current historically september of 2006, a evolution of this indicator helps to explain, in part, the recent rating improvements obtained by Brazil. However, one can observe in the graph that the Median for this ratio is still the Brazilian number, which made, either through the opening of the account receipts), or through the obtaining of a surplus in current account plus direct investment plus stock investment, which will make a reduction of net external debt possible. 
The graphs were prepared with the year 2004 as a reference using risk classifications for each country from an average composed from data of the three principal agencies: Fitch, Standard and Poor's, and Moody's. The abscissa of the graphs ("risk classification") represents this average, which is calculated considering the number 1 as the highest risk classification (AAA for S\&P and Fitch, Aaa for Moody's.) The number 2 corresponds to the next lower classification (AA+ for S\&P and Fitch, Aa1 for Moody's), and so on. The classification that separates investment grade (above BBB- for S\&P and Fitch and above Baa3 for Moody's) from speculative grade is represented by the number 10 .

As mentioned in table 1, an important factor in the determination of sovereign risk is stability: the stability of institutions and political stability. This is important, for example, when the country goes through periods of shock in external offers, which require a currency devaluation usually accompanied by a drop in real salaries. Institutional stability, meanwhile, represents a positive correlation with per capita income in a country. It's not surprising then, that per capita income appears as an important variable in the determination of ratings. Illustration 4 shows this correlation between rating quality and per capita income for the group of countries analyzed.

\section{Illustration 4: GDP Per Capita vs. Risk Classification: Selected Countries}

\section{GDP per Capita vs. Risk Classification}

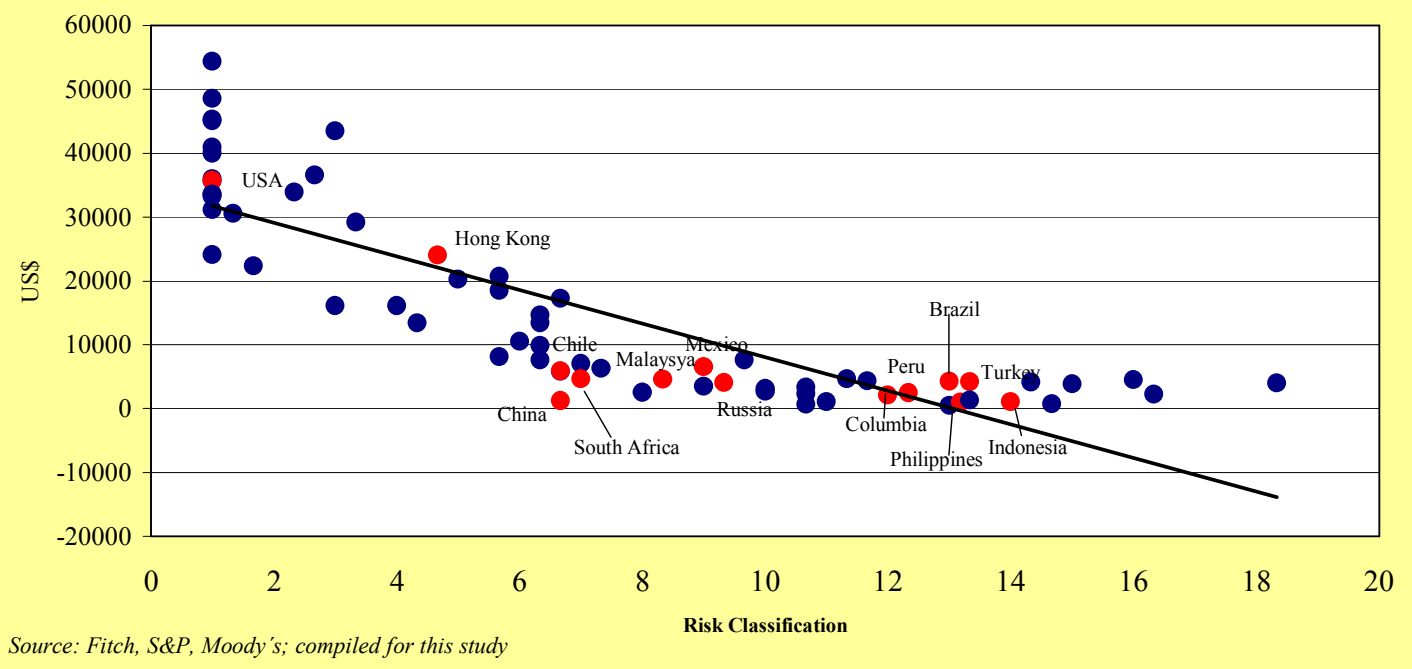

As the quality of the rating drops with the value of the abscissa, a cross section estimation is seen as a negatively sloped vector. It is interesting to observe that Brazil, if it had its rating measured using only this variable, would have a higher average rating classification than it does (because it is above the estimated vector). China is found to be in a diametrically opposed situation, with a per capita income of only US\$1,253, but with an investment grade classification (average rating of 6.66, much higher than Brazil, with a rating of 13.)

An advantage that China has in regard to Brazil is that its growth rate over the last several years has been between three and four times higher than ours. The relationship between government debt and current receipts of the government is also more favorable for China. Chile is another country with a per capita income that is slightly higher to 
that of Brazil (US\$ 5899 in Chile against US\$ 4320 in Brazil), but a classification rating that is much better. In regard to the relationship between rating and per capita income, Brazil (with an average rating of 13 and per capita income of US\$ 4320) and Turkey (average rating of 13.33, slightly poorer than Brazil, and per capita income of US\$ $4210)$ are very similar. The graph that follows shows the estimate for growth rates.

\section{Illustration 5: GDP Growth vs. Risk Classification: Selected Countries}

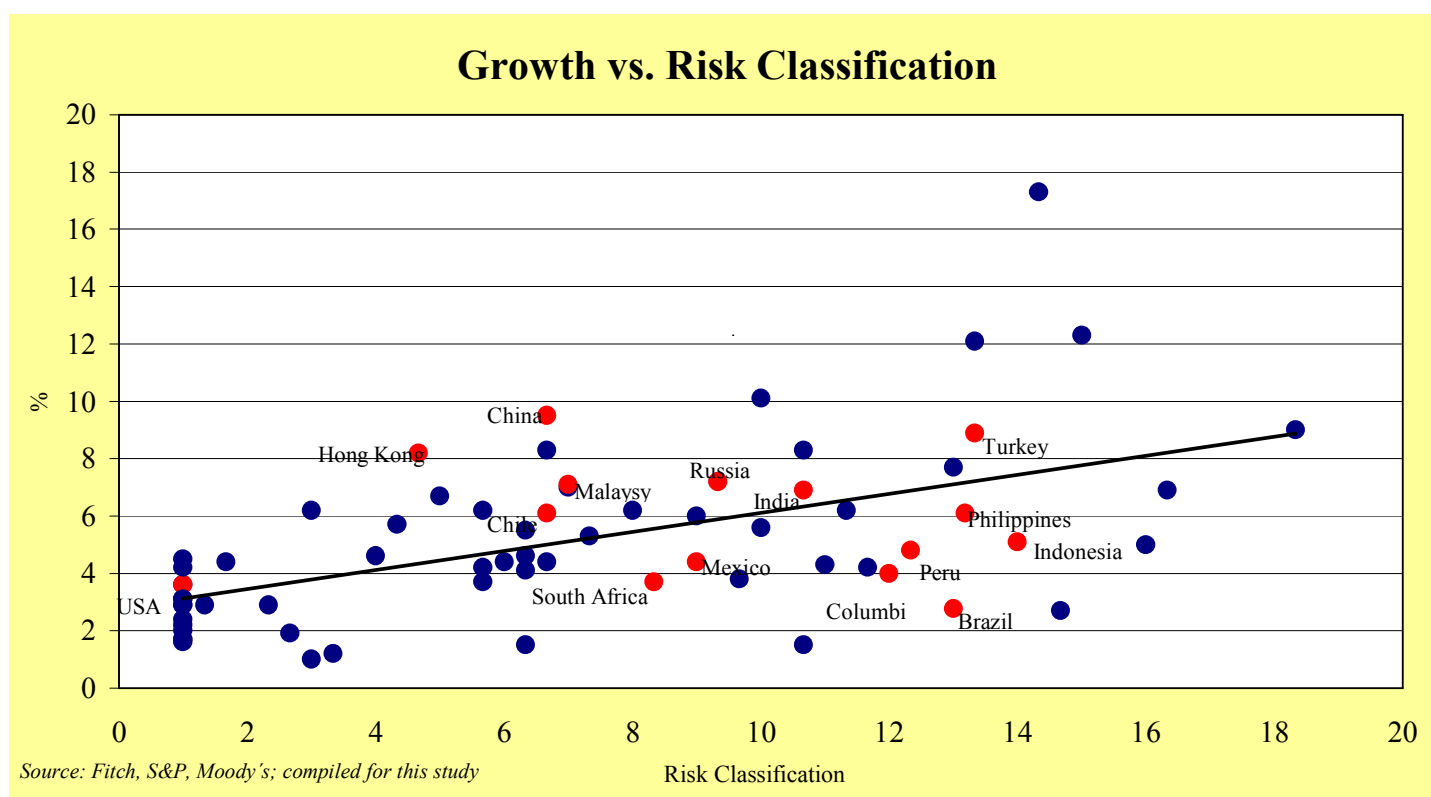

In principal, one might expect that higher growth rates would be associated with a better rating, which would result in a negative inclination of the vector estimated above. It happens, however, that all of these estimates only result from simple correlations, and are deceptive due to the omission of other variables.

We show in the Appendix, where the multiple regression is presented, that the coefficient in this case is positive, although it is not statistically significant.

In general, the principal trend observed here results from the fact that emerging countries grow at faster rates and, at the same time, are subject, in principle, to lower ratings. That said, a way to improve the results would be to divide the regressions above by categories of per capita income.

Two more important variables, as we saw earlier, are inflation and the government's nominal result: 


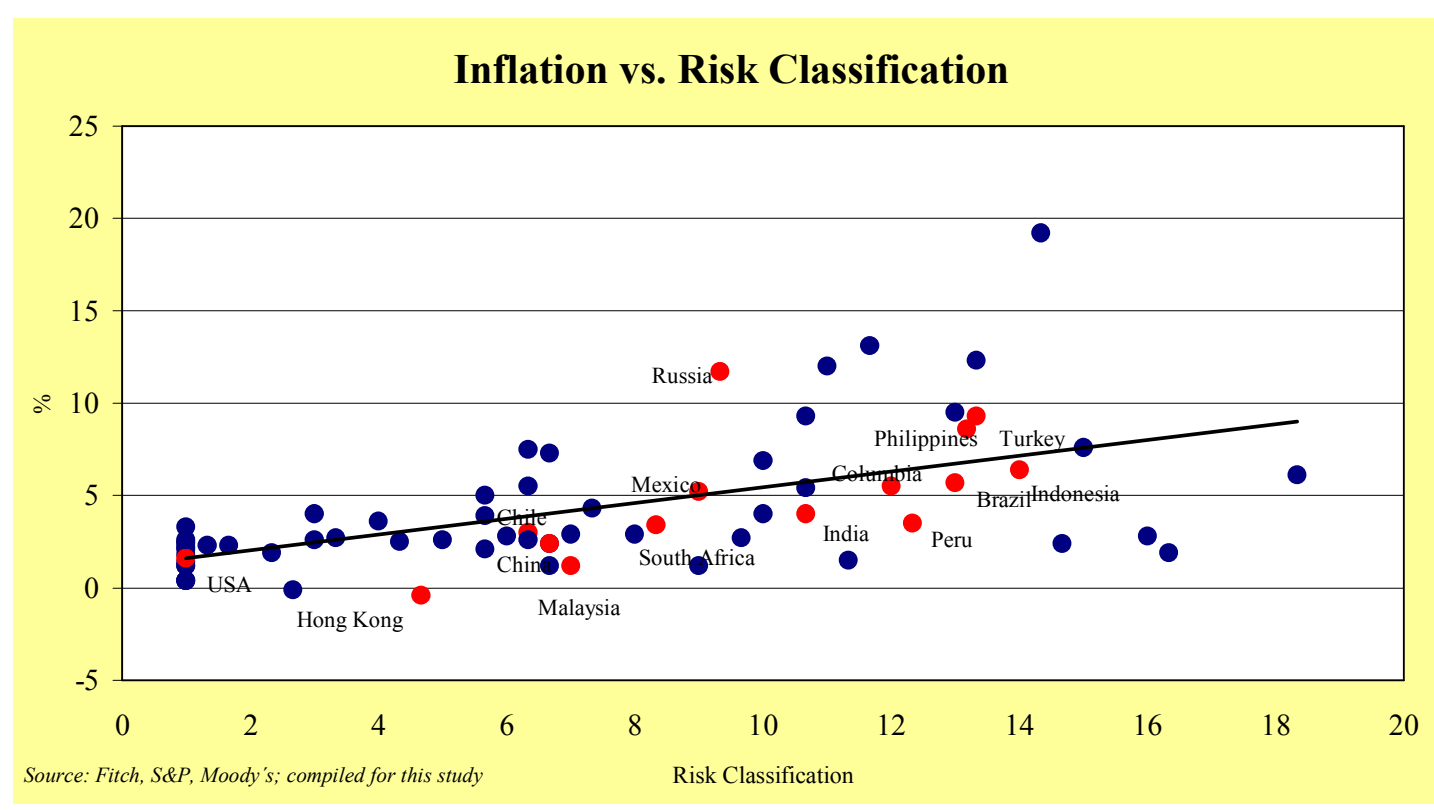

IIlustration 7: Government Deficit vs. Risk Classification: Selected Countries

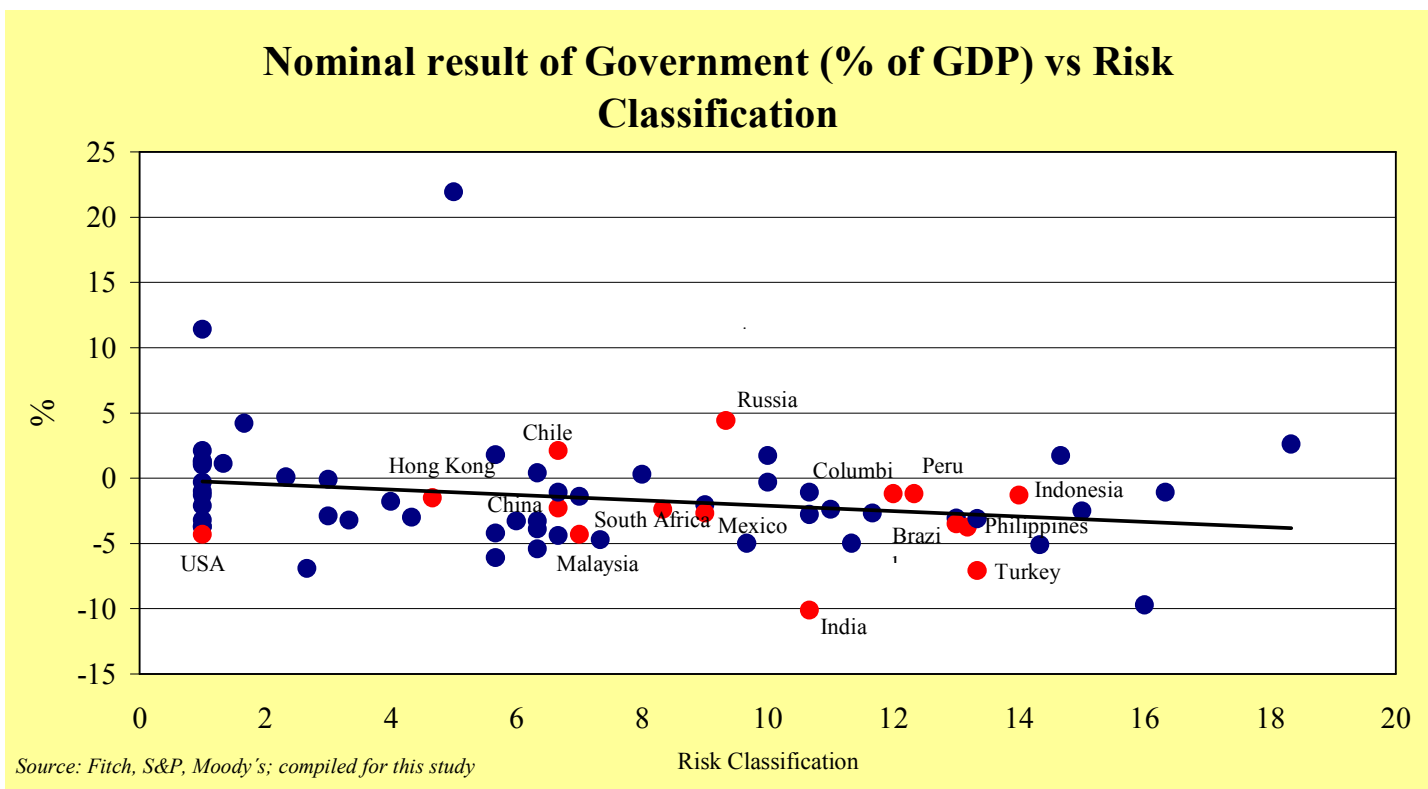

It is also important to consider the relationship between public sector debt and the government's current receipts. This is an indicator of solvency that, like the indicator net debt / total current receipts of the balance of payments, divides a stock of obligations by a flow of revenues. The resulting number has the dimension of time. One of the drawbacks of this indicator, apparently, is that it gives no information about the maturity of the debt, which may be long-term or short-term. Illustration 8 shows that the greater the relationship between public debt and public receipts, the greater is the number associated with the rating (which, because of the convention adopted, means the lower the quality). 
Illustration 8: Public debt vs. Risk Classification: Selected Countries

Public Debt (\% of Receipts) vs. Risk Classification

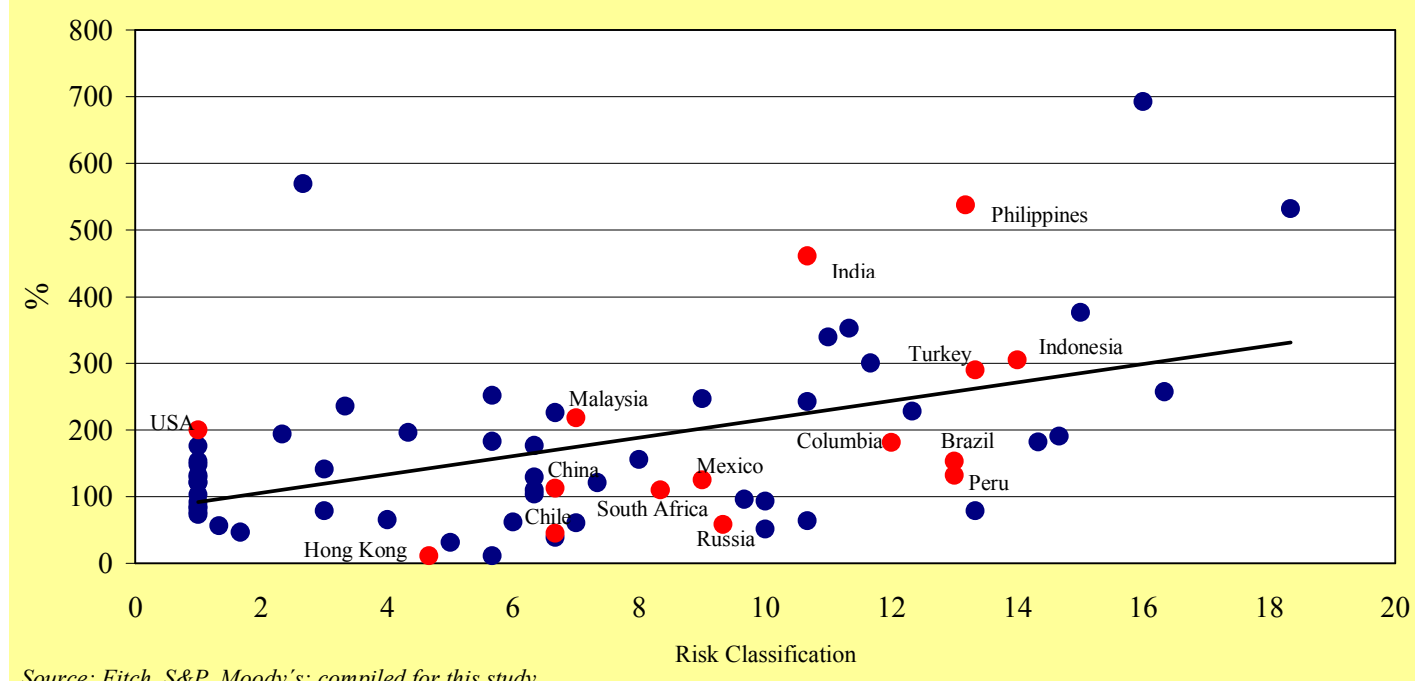

Source: Fitch, S\&P, Moody's; compiled for this study

For this variable at least, Brazil would have a better rating than the one shown in practice. The same is true for China, Chile and Russia, but not for Turkey or, for other reasons, the United States.

Contrary to common sense, the deficit in current account, which reflects a country's the excess investment in savings, usually shows just a small positive correlation with the quality of the rating. This occurs because in many situations a deficit in current account isn't a result of the adoption of the wrong economic policies.

As an example, various countries of Eastern Europe that are now a part of the European Union have high current account deficits which are not associated with poor economic management. On the other hand, the crisis in Thailand in 1997 is also a warning that high current account deficits can be a sign of problems - in this case, the low quality of investments that follow an excess in the supply of domestic credit. This low correlation between current account deficits and sovereign risk is clear in Illustration 9 that follows. 
Illustration 9: Current Account vs. Risk Classification: Selected Countries

\section{Current Account Result (\% of GDP) vs. Risk Classification}

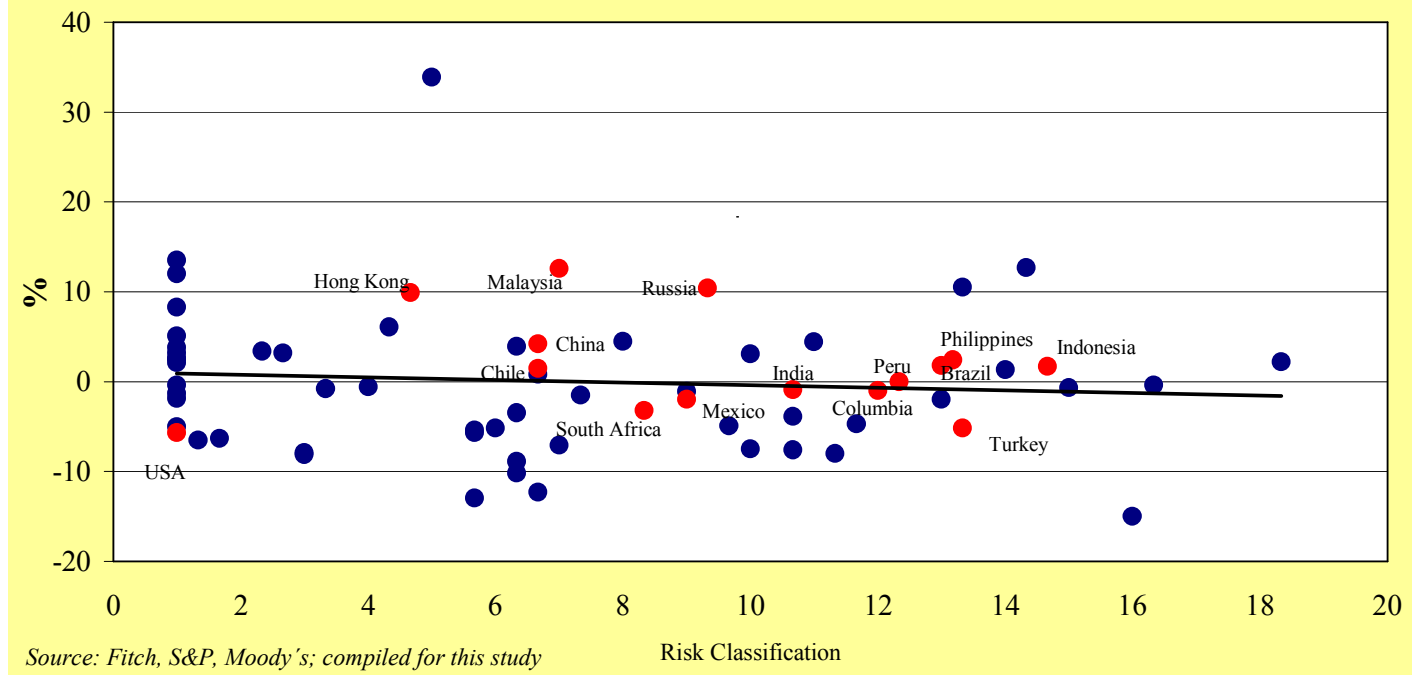

The asymmetric situation between Brazil and Turkey is made clear in this graph. While Brazil, in 2005, presented a current account balance of $1.8 \%$ of GDP, Turkey, while maintaining a classification rating almost the same as that of Brazil, presented a deficit on the order of $5.2 \%$ of GDP. Moreover, if we looked at the situation solely from this perspective, the United States should have a classification rating much lower than it has, and the opposite would be true of Hong Kong.

The dependence between the degree of openness (imports plus exports of goods / GDP) and the average sovereign risk classification also doesn't appear to be very important in the overall correlation (which doesn't tell us much because it doesn't take into consideration the effect of all of the other variables), as we can see in illustration 10.

There is a slightly negative correlation, as could be expected, between the degree of openness and the numeric scale of the ratings. As the scale has a negative correlation with the quality of the ratings, by design, this implies that more open countries, all things being equal, usually receive better classifications from the agencies. Brazil and the United States, relatively closed countries, would have much lower ratings than they actually have if this were the only variable taken into consideration. In the opposite situation are, for example, Malaysia and Hong Kong, countries in which the various lines of exports are a consequence of concomitant imports. 
Illustration 10: Trade Openness vs. Risk Classification: Selected Countries

\section{Trade Openness vs. Risk Classification}

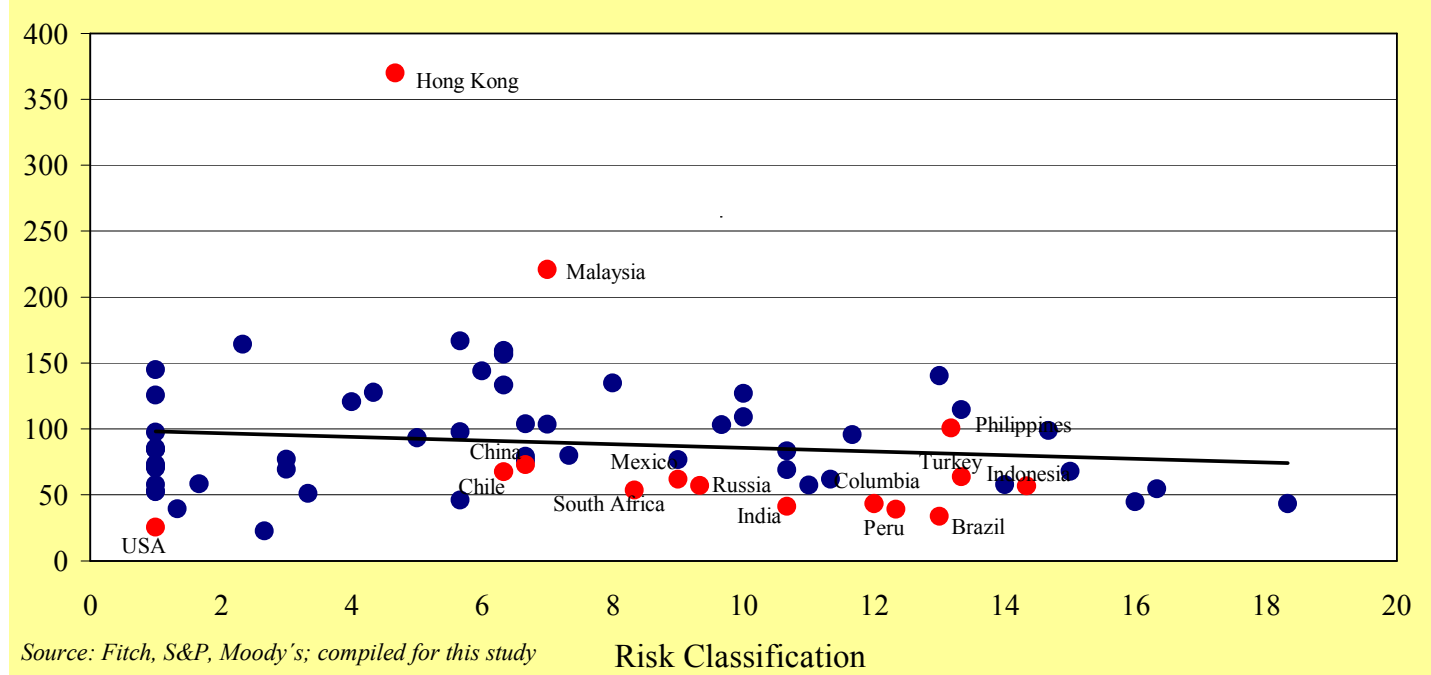

Another important variable in the determination of ratings is the relationship between net debt and total current receipts in the balance of payments. Once again, in Illustration 11 below, we present the data for the different countries:

Illustration 11: External Debt vs. Risk Classification: Selected Countries

\section{Net External Debt (\% receipts in CA) vs. Risk Classification}

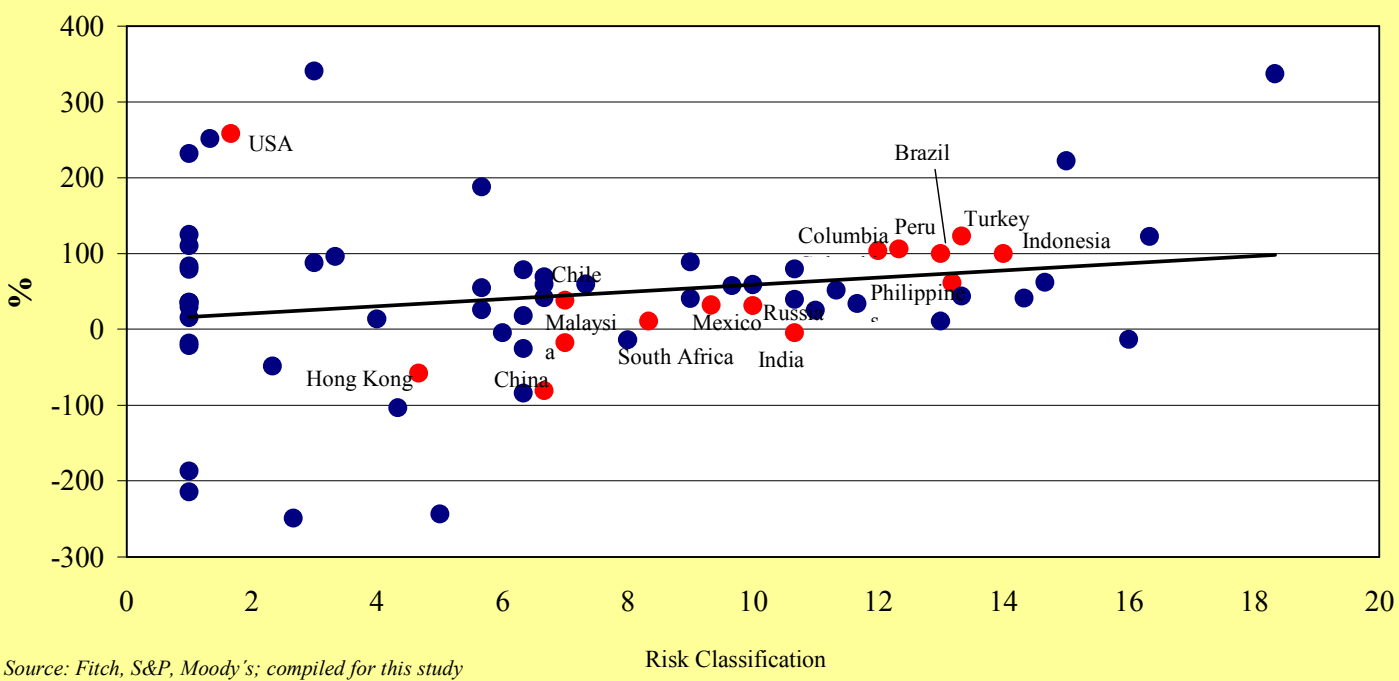

Just based upon this indicator, Brazil would have a poorer rating than the one it is given. One of the reasons for this is that Brazil is a relatively closed country, particularly when compared to countries that function as "export corridors" (Hong Kong, for example). Turkey is in the same situation and, to a lesser degree, the United States. Hong Kong 
and China are examples of the opposite, where the rating observed is lower than that which would be obtained if it were based solely on this indicator.

\section{Partial Correlation in the Case of the Ratio of Net Debt / Exports}

In order to attempt to filter out the influence on the rating of all of the other variables that don't have a relationship with external debt and total current receipts, we perform a retrogression on the ratings with all of these other variables and, after obtaining the residuals, we perform the regression of these against the CAR (Current Account Receipts) variable. Observe that this doesn't require the obtaining of a coefficient of multiple regression, since we are not performing the regression of residuals against residuals. According to the new result, Brazil is exactly in the middle, while the United States on one side and China and Hong Kong on the other, maintain there previous positions (above the average and below the average, respectively.) The result is presented in Illustration 12 to follow:

Illustration 12: Net External Debt vs. Risk Classification: Selected Countries

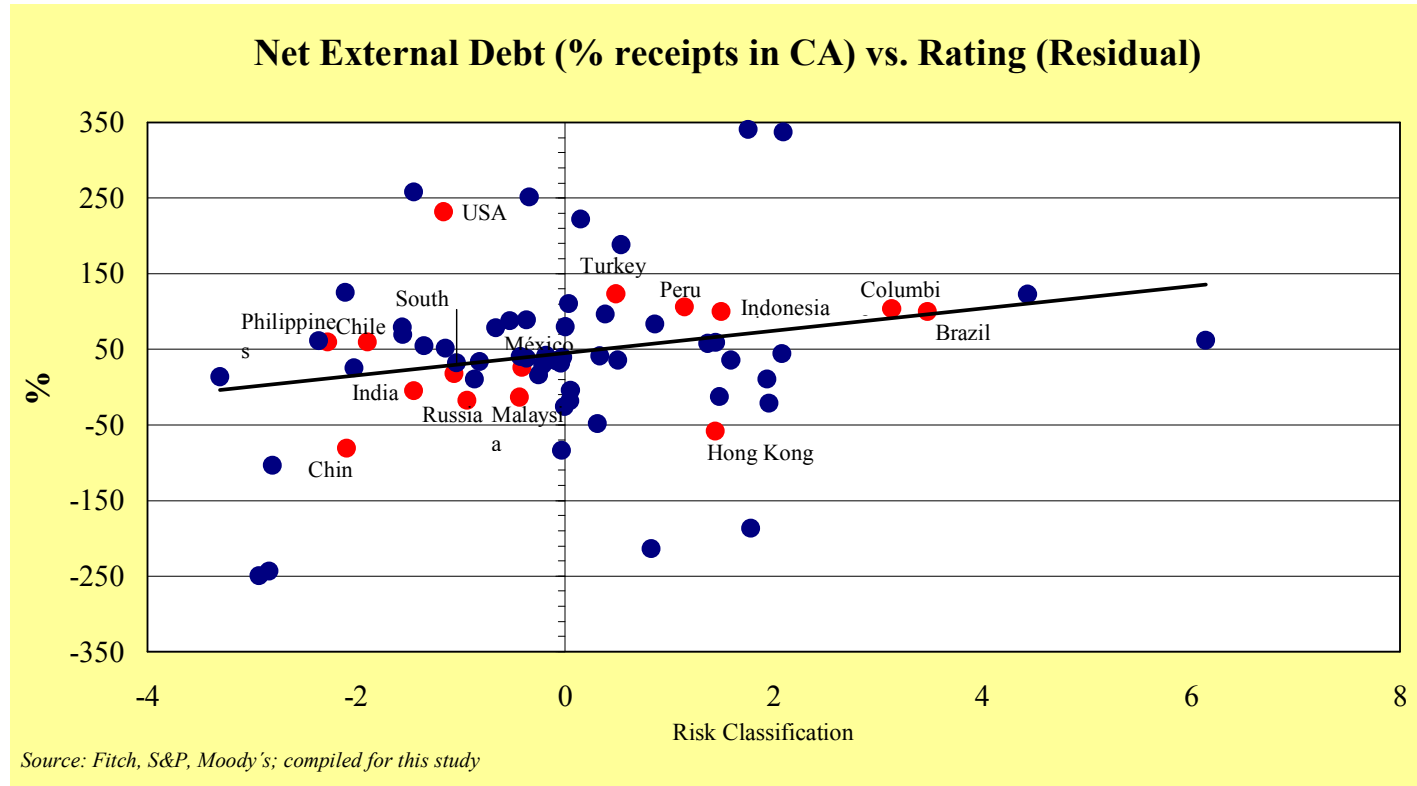

\section{Appendix}

The graphs in section 3 ("Determinants of Sovereign risk") only show a simple correlation between sovereign risk classification (rating) and each one of the variables analyzed. Such a procedure is useful from an illustrative point of view, but has the serious problem of bringing biases into each of the estimates performed. This happens because the explicative variables used are not orthogonal from each other.

The table A1 below gives a multivariable regression of sovereign risk classification for the 68 countries analyzed (2004). Its relative advantage compared to the illustrations in section 3, is to give estimates that, in principal, are not biased (assuming that all of the 
relevant explicative variables have been included in the regression) by the effect of each variable on the rating.

Table A1: Determinants of Sovereign Risk

\begin{tabular}{|c|c|c|c|c|}
\hline \multicolumn{5}{|c|}{ Determinants of Rating - Year 2004} \\
\hline \multirow[b]{2}{*}{ Variable } & \multicolumn{4}{|c|}{ Dependent variable: Rating } \\
\hline & Average Rating of 3 & Fitch & S\&P & Moody's \\
\hline \multirow[t]{2}{*}{ Constant } & 5.520 & 5.133 & 6.067 & 53.590 \\
\hline & $(1.30)^{\star * *}$ & $(1.51)^{\star \star *}$ & $(1.31)^{\star \star *}$ & $(1.35)^{\star * *}$ \\
\hline \multirow[t]{2}{*}{ GDP per capita } & -0.00010 & -0.00009 & -0.00009 & -0.00011 \\
\hline & $(0.0004)^{\star *}$ & $(0.0004)^{* *}$ & $(0.0004)^{* \star}$ & $(0.0004)^{* *}$ \\
\hline \multirow[t]{2}{*}{ Growth Rate } & 0.157 & 0.110 & 0.167 & 0.193 \\
\hline & $(0.130)$ & $(0.137)$ & $(0.125)$ & $(0.140)$ \\
\hline \multirow[t]{2}{*}{ Inflation } & 0.107 & 0.109 & 0.131 & 0.081 \\
\hline & $(0.097)$ & $(0.097)$ & $(0.094)$ & $(0.110)$ \\
\hline \multirow[t]{2}{*}{ Nominal Result of Government (\% GDP) } & 0.072 & 0.102 & 0.043 & 0.070 \\
\hline & $(0.078)$ & $(0.092)$ & $(0.072)$ & $(0.085)$ \\
\hline \multirow[t]{2}{*}{ General Government Debt (\% receipts) } & 0.012 & 0.014 & 0.011 & 0.012 \\
\hline & $(0.002)^{* * * *}$ & $(0.003)^{\star * *}$ & $(0.002)^{\star * \star *}$ & $(0.002)^{\star * * *}$ \\
\hline \multirow[t]{2}{*}{ Current Account result (\% GDP) } & 0.008 & 0.005 & 0.001 & 0.018 \\
\hline & $(0.044)$ & $(0.045)$ & $(0.041)$ & $(0.050)$ \\
\hline \multirow[t]{2}{*}{ Degrre of Openness } & -0.001 & 0.001 & -0.003 & -0.001 \\
\hline & $(0.044)$ & $(0.005)$ & $(0.006)$ & $(0.004)$ \\
\hline \multirow[t]{2}{*}{ Net External Debt (\% receipts in CA) } & 0.006 & 0.010 & 0.005 & 0.005 \\
\hline & $(0.003)^{* \star}$ & $(0.002)^{* *}$ & $(0.003)^{* * *}$ & $(0.003)$ \\
\hline \multirow[t]{2}{*}{ Industrialization Indicator } & -3.278 & -3.568 & -3.365 & -2.901 \\
\hline & $(1.01)^{* * *}$ & $(1.16)^{\star \star \star}$ & $(0.985)^{* * *}$ & $(1.10)^{\star *}$ \\
\hline \multirow[t]{2}{*}{ Moratorium Indicator } & 1.584 & 1.409 & 1.272 & 2.070 \\
\hline & $(0.84)^{*}$ & $(0.84)^{*}$ & $(-0.835)$ & $(0.93)^{* *}$ \\
\hline F Statistic & 44.02 & 37.90 & 43.94 & 36.99 \\
\hline Prob (F Statistic) & 0.00 & 0.00 & 0.00 & 0.00 \\
\hline Adjusted R2 & 0.86 & 0.85 & 0.86 & 0.84 \\
\hline Number of Observations & 68 & 68 & 68 & 68 \\
\hline
\end{tabular}

${ }^{* * *}$ Significant to $1 \%,{ }^{* *}$ significant to $5 \%,{ }^{*}$ significant to $10 \%$, Standard error in parentheses. 


\section{Sites accessed:}

The Institute of International Finance (IIF): www.iif.com

World Bank International Economics \& Trade: econ.worldbank.org

Banco Central do Brasil: www.bcb.com.br

Ministério do Desenvolvimento: www.desenvolvimento.gov.br

Fundação centro de estudos do comércio externo (FUNCEX): www.funcex.com.br

United Nations. Comtrade Database: unstats.un.org/unsd/comtrade

Standard and Poor's: www.sandp.com

Fitch Ratings: www.fitchratings.com

Moody's Investor Service: www.moodys.com

Rubens Penha Cysne: http://www2.fgv.br/professor/rubens/ 